\title{
ANALISIS FAKTOR-FAKTOR PENENTUAN NILAI KOMPENSASI TERHADAP SUMBER DAYA MANUSIA
}

\author{
Tri Darmawati *)
}

\begin{abstract}
ABSTRAK
Salah satu tujuan yang diinginkan dalam manajemen sumber daya manusia adalah pencapaian tujuan organisasi. Untuk itu salah satu variabel yang harus menjadi perhatian bagi pimpinan organisasi dalam menjalankan roda organisasi adalah kompensasi. Beberapa faktor yang dapat menentukan nilai kompensasi bagi seorang pegawai di suatu organisasi adalah penawaran dan permintaan tenaga kerja, kemampuan dan kesediaan perusahaan, serikat buruh atau organisasi karyawan, produktivitas kerja karyawan, pemerintah dengan undang-undang dan keppres, biaya hidup atau cost of living, posisi jabatan karyawan, pendidikan dan pengalaman karyawan, kondisi perekonomian nasional, jenis dan sifat pekerjaan. Sedangkan langkah-langkah yang harus dilakukan dalam rangka menentukan nilai kompensasi bagi seorang pegawai disuatu organisasi adalah menganalisis jabatan, mengevaluasi jabatan, melakukan survey gaji dan upah, kemudian terakhir menentukan tingkat gaji.
\end{abstract}

Kata kunci: Sumber daya manusia, organisasi, kompensasi.

\section{A. Latar Belakang}

Salah satu tujuan yang diinginkan dalam manajemen sumber daya manusia adalah pencapaian tujuan organisasi. Menurut Sihotang (2007:10) manajemen sumber daya manusia adalah keseluruhan proses perencanaan, pengorganisasian, pengarahan, dan pengawasan terhadap kegiatan pengadaan seleksi, pelatihan, penempatan, pemberian kompensasi, pengembangan, pengintegrasian, pemeliharaan dan pelepasan sumber daya manusia untuk tercapainya berbagai tujuan individu, masyarakat dan organisasi yang bersangkutan. Untuk melihat bagaimana kedudukan suatu organisasi sangatlah penting untuk mengetahui apa itu sebenarnya organisasi dan bagaimana kaitannya dengan manajemen sumber daya manusia bahkan dengan pemberian kompensasi bagi seorang pegawai.

Menurut Miles dalam Gomes (2003:23) organisasi tidak lebih daripada sekelompok orang yang berkumpul bersama disekitar suatu teknologi yang dipergunakan untuk mengubah input-input dari lingkungan menjadi barang atau jasa yang dapat dipasarkan. Dari defenisi tersebut dapat dikatakan bahwa unsur manusia mempunyai kedudukan yang strategis untuk mengolah atau mentransformasikan input-input yang ada menjadi output yang diinginkan.

Hal ini disebabkan kompensasi bisa diberikan dengan beberapa macam dan memiliki dampak yang akan mempengaruhi kinerja pegawai sehingga berimplikasi terhadap pencapaian tujuan organisasi. Jika diatur secara tepat, kompensasi dapat membantu organisasi dalam meningkatkan kinerja pegawai dan mencapai tujuan-tujuan organisasi serta mendapatkan, memelihara, bahkan mempertahankan pegawaipegawai yang unggul dan produktif.

Kompensasi yang diberikan dapat berupa uang tunai secara langsung, imbalan tidak langsung dalam bentuk maslahat tambahan (benefit), pelayanan, dan insentif untuk memotivasi pegawai agar mencapai produktivitas yang lebih tinggi. Pemberian kompensasi diharapkan merupakan salah satu cara bagi pimpinan organisasi untuk meningkatkan kinerja pegawai. Pentingnya kompensasi sebagai salah 
satu indikator kepuasan dalam bekerja sulit ditaksir, karena pandanganpandangan pegawai mengenai uang atau imbalan langsung nampaknya sangat subjektif dan barang kali merupakan sesuatu yang sangat khas dalam suatu organisasi. Tetapi pada dasarnya dugaan adanya ketidakadilan dalam memberikan gaji merupakan sumber ketidakpuasan pegawai terhadap kompensasi yang pada akhirnya bisa menimbulkan perselisihan dan semangat rendah dari karyawan itu sendiri.

$\begin{array}{lcr}\text { Sebagian } & \text { besar } & \text { pegawai } \\ \text { menganggap kompensasi } & \text { sangat } \\ \text { penting, oleh } & \text { karena } & \text { mereka } \\ \text { menganggap } & \text { bahwa } & \text { besaran }\end{array}$ kompensasi mencerminkan ukuran nilai karya mereka diantara pegawai itu sendiri. Tidaklah mudah merancang dan mengelola sebuah sistem kompensasi atau sistem imbalan yang efektif. Kompensasi dipengaruhi oleh kekuatan-kekuatan seperti faktor pasar tenaga kerja, kompetisi, kesepakatan kerja, peraturan pemerintah, dan filosofi manajemen puncak mengenai pemberian gaji atau upah dan maslahat serta berbagai faktor lain. Implementasi manajemen dan sistem kompensasi juga seringkali menjadi isu yang peka dalam sebuah organisasi, karena pada dasarnya tujuan yang hendak dicapai adalah terwujudnya imbalan yang adil dan layak bagi seluruh anggota organisasi. Berdasarkan beberapa hal diatas tersebut penulis tertarik untuk menganalisis:

1. Faktor-faktor apa saja yang dapat menentukan nilai kompenasi bagi seorang pegawai disuatu organisasi?

2. Bagaimana langkah-langkah yang harus dilakukan dalam rangka menentukan nilai kompensasi bagi seorang pegawai disuatu organisasi?
Sehingga tujuan dari penulisan kajian ini adalah untuk mengetahui:

1. faktor-faktor yang dapat menentukan nilai kompensasi bagi seorang pegawai disuatu organisasi.

2. langkah-langkah yang harus dilakukan dalam rangka menentukan nilai kompensasi bagi seorang pegawai disuatu organisasi.

\section{B. Kompensasi}

Kompensasi merupakan salah satu aspek penting dalam manajemen sumber daya manusia karena kompensasi merupakan salah satu aspek yang paling sensitif di dalam hubungan kerja. Menurut Sutrisno (2009:181) kasus yang terjadi dalam hubungan kerja mengandung masalah kompensasi dan berbagai segi yang terkait, seperti tunjangan, kenaikan kompensasi, struktur kompensasi, dan skala kompensasi. Dalam praktiknya masih banyak perusahaan yang belum memahami secara benar sistem kompensasi. Sistem kompensasi membantu dalam memberi penguatan terhadap nilai-nilai kunci organisasi serta memfasilitasi pencapaian tujuan organisasi. Kompensasi adalah keseluruhan imbalan yang diberikan kepada para karyawan sebagai balasan atas jasa atau kontribusi mereka terhadap organisasi.

Menurut Singodimedjo (2000:185) kompensasi adalah semua balas jasa yang diterima seorang karyawan dari perusahaannya sebagai akibat dari jasa atau tenaga yang telah diberikannya pada perusahaan tersebut. Kompensasi sering disebut sebagai penghargaan dan dapat didefinisikan sebagai setiap bentuk penghargaan yang diberikan pada pegawai sebagai balas jasa atas kontribusi yang mereka berikan kepada organisasi. 
Menurut Werther dan Davis dalam Hasibuan (2009:119) "compensation is what employee receive in exchange of their work. Whether hourly wages or periodic salaries, the personnel department usually designs and administers employee compensation. Kompensasi adalah apa yang seorang pekerja terima sebagai balasan dari pekerjaan yang diberikannya. Baik upah per jam ataupun gaji periodik didesain dan dikelola oleh bagian personalia. Sedangkan menurut Sikula dalam Hasibuan (2009:119) "a compensation is anything that constitutes or is regarded as an equivalent or recompense". Kompensasi adalah segala sesuatu yang dikonstitusikan atau dianggap sebagai suatu balas jasa atau ekuivalen.

Menurut Handoko dalam singodimedjo (2000:185), kompensasi adalah segala sesuatu yang diterima oleh karyawan sebagai balas jasa untuk kerja mereka. Kompensasi dapat diberikan dalam berbagai macam bentuk, seperti: pemberian uang, pemberian material dan fasilitas, dan dalam bentuk pemberian kesempatan berkarir. Sedangkan Tohardi dalam singodimedjo (2000:185), mengemukakan bahwa kompensasi dihitung berdasarkan evaluasi pekerjaan, perhitungan kompensasi berdasarkan evaluasi pekerjaan tersebut dimaksudkan untuk mendapatkan pemberian kompensasi yang mendekati kelayakan (worth) dan keadilan (equity). Karena bila kompensasi dirasakan tidak layak dan tidak adil oleh para karyawan, maka tidak mustahil hal tersebut merupakan sumber kecemburuan sosial. Untuk itulah paling tidak kecemburuan sosial tersebut dapat ditekan atau dapat diminimalkan serendah mungkin, maka perlu tindakan preventif. Pemberian kompensasi yang layak dan adil tersebut merupakan kata kunci dalam upaya mendekati pemberian upah yang layak dan adil tersebut.

Pada prinsipnya, pemberian kompensasi itu merupakan hasil penjualan tenaga para sumber daya manusia terhadap perusahaan. Namun dalam hal ini terkandung pula pengertian bahwa para karyawan telah memberikan segala kemampuan kerjanya kepada perusahaan, maka perusahaan sewajarnya menghargai jerih payah karyawan itu dengan cara memberi balas jasa yang setimpal kepada mereka. Sebenarnya hubungan antara perusahaan dan karyawan tidak ubahnya seperti hubungan antara pihak penjual dan pembeli di pasar. Perusahaan sebagai pembeli jasa, menawarkan pekerjaan kepada karyawan (pencari kerja), sedangkan karyawan bersedia menjual jasa atau tenaga kepada perusahaan. Sebagai imbalan dari menjual atau memberikan tenaga ini, maka perusahaan memberikan imbalan atau kompensasi kepada karyawan atas jasa yang telah diberikannya itu. Jadi, hubungan antara perusahaan dan karyawan sudah merupakan hubungan simbiosis mutualisme.

Agar kompensasi terasa adil, maka evaluasi pekerjaan, survei kompensasi, dan penilaian prestasi kerja merupakan serangkaian kegiatan yang perlu dilakukan dalam pemberian kompensasi. Penilaian pekerjaan atau evaluasi pekerjaan merupakan suatu proses yang digunakan untuk menentukan nilai relatif dari berbagai pekerjaan, antara lain dengan cara membandingkan nilai suatu jabatanjabatan lain yang ada dalam suatu perusahaan. Selain itu perlu dilakukan survei mengenai jumlah kompensasi yang diberikan atas pekerjaan itu dibandingkan dengan perusahaan lain.

Bagi organisasi atau perusahaan, kompensasi memiliki arti penting 
karena kompensasi mencerminkan upaya organisasi dalam mempertahankan dan meningkatkan kesejahteraan pegawainya.

Pengalaman menunjukkan bahwa kompensasi yang tidak memadai dapat menurunkan prestasi kerja, motivasi kerja, dan kepuasan kerja pegawai, bahkan dapat menyebabkan pegawai yang potensial keluar dari organisasi. Supaya efektif, kompensasi seharusnya dapat memenuhi kebutuhan dasar, mempertimbangkan adanya keadilan internal dan eksternal, dan pemberiannya disesuaikan dengan kebutuhan individu. Jadi, dapat disimpulkan bahwa kompensasi adalah semua jenis penghargaan yang berupa uang atau bukan uang yang diberikan kepada karyawan secara layak dan adil atas jasa mereka dalam mencapai tujuan perusahaan.

\section{Komponen-komponen Tujuan Kompensasi}

dan

Menurut rivai dan sagala (2010:746) Komponen-komponen kompensasi adalah sebagai berikut.

1. Gaji, yaitu balas jasa dalam bentuk uang yang diterima karyawan sebagai konsekuensi dari kedudukannya sebagai seorang karyawan yang memberikan sumbangan tenaga dan pikiran dalam mencapai tujuan perusahaan. Atau dapat juga dikatakan sebagai bayaran tetap yang diterima seseorang dari keanggotaannya dalam sebuah perusahaan.

2. Upah, yaitu imbalan finansial langsung yang dibayarkan kepada karyawan berdasarkan jam kerja, jumlah barang yang dihasilkan atau banyaknya pelayanan yang diberikan.

3. Insentif, yaitu imbalan langsung yang dibayarkan kepada karyawan karena kinerjanya melebihi standar yang ditentukan. Insentif merupakan kompensasi tetap, yang biasa disebut kompensasi berdasarkan kinerja.

4. Kompensasi Tidak langsung (Fringe Benefit), yaitu kompensasi tambahan yang diberikan berdasarkan kebijakan perusahaan terhadap semua karyawan sebagai upaya meningkatkan kesejahteraan para karyawan. Contohnya berupa fasilitasfasilitas, seperti asuransi-asuransi, tunjangan-tunjangan, dan uang pensiunan.

Suatu kegiatan yang dilakukan biasanya ada tujuan yang ingin dicapai, atau minimal kegiatan tersebut diusahakan mengarah atau mendekati hal yang ingin dicapai. Menurut Singodimedjo (2000:186), pemberian kompensasi kepada para karyawan juga mempunyai tujuan, antara lain menjamin sumber nafkah karyawan beserta keluarganya, meningkatkan prestasi kerja, meningkatkan harga diri para karyawan, mempererat hubungan kerja antar karyawan, mencegah karyawan meninggalkan perusahaan, meningkatkan disiplin kerja, efisiensi tenaga karyawan yang potensial, perusahaan dapat bersaing dengan tenaga kerja di pasar, mempermudah perusahaan mencapai tujuan, melaksanakan peraturan perundangundangan yang berlaku, dan perusahaan dapat memberikan teknologi baru.

Manajemen kompensasi berkaitan dengan upaya memformulasikan dan mengimplementasikan strategi dan kebijakan kompensasi. Manajemen kompensasi dalam sebuah organisasi dalam mewujudkan keberhasilan jangka panjang (yang bersifat strategis). Secara umum pemberian manajemen kompensasi adalah untuk 
membantu organisasi dalam mencapai tujuan keberhasilan strategi dan menjamin terciptanya keadilan baik keadilan internal maupun keadilan eksternal.

Menurut Hasibuan (2009:121) tujuan dari kompensasi antara lain sebagai berikut:

1. Ikatan Kerjasama, yaitu agar terjalin ikatan kerjasama antara majikan dengan pegawai, dimana pegawai harus mengerjakan tugastugasnya dengan baik, sedangkan pengusaha atau majikan wajib membayar kompensasi sesuai dengan perjanjian.

2. Kepuasan Kerja, yaitu dengan balas jasa, pegawai akan dapat memenuhi kebutuhan-kebutuhan fisik, status sosial dan egoistiknya sehingga ia memperoleh kepuasan kerja dari jabatannya itu.

3. Pengadaan Efektif, yaitu jika program kompensasi ditetapkan cukup besar maka pengadaan pegawai yang berkualitas untuk organisasi itu akan lebih mudah.

4. Motivasi, yaitu jika balas jasa yang diberikan memotivasi bawahannya cukup besar, manajemen akan lebih mudah memotivasi bawahannya. Menurut Djaali (2011:101) Motivasi adalah keadaan yang terdapat dalam diri seseorang yang mendorongnya untuk melakukan aktivitas tertentu guna pencapaian suatu tujuan.

5. Stabilitas Pegawai, yaitu dengan program kompensasi atas prinsip adil dan layak serta eksternal konsistensi yang kompetitif, maka stabilitas pegawai lebih terjamin karena turn over relatif kecil.

6. Disiplin, yaitu dengan pemberian balas jasa yang cukup besar maka disiplin pegawai semakin baik, mereka akan menyadari serta mentaati peraturan yang berlaku.
7. Pengaruh Serikat Buruh, yaitu dengan kompensasi yang baik maka pengaruh serikat buruh dapat dihindarkan dan karyawan akan berkonsentrasi pada pekerjaannya.

8. Pengaruh Pemerintah, yaitu jika kompensasi sesuai dengan Undang-undang yang berlaku maka intervensi pemerintah dapat dihindarkan.

Tujuan pengembangan kompensasi bukanlah aturan yang harus dengan kaku diikuti dan dijalankan, akan tetapi lebih kepada pedoman dalam pemberian upah/gaji kepada para pegawainya. Semakin baik pengaturan gaji dan upah suatu organisasi maka akan semakin baik pula gaji atau upah tersebut diterima oleh para pegawainya. Pengaturan kompensasi haruslah memenuhi beberapa tujuan. Kadang-kadang tujuan ini akan bertentangan satu sama lainnya.

Kompensasi merupakan alat pengikat organisasi terhadap pegawainya, faktor penarik bagi calon pegawai dan faktor pendorong seseorang menjadi pegawai. Dengan demikian kompensasi mempunyai fungsi yang cukup penting di dalam memperlancar jalannya roda organisasi.

Sunyoto (2015:157) mengatakan adanya kompensasi yang baik akan menjamin terjadinya keadilan di antara karyawan dalam organisasi. Administrasi pengupahan dan penggajian berusaha untuk memenuhi prinsip keadilan. Keadilan sangat penting diperhatikan dalam penentuan tingkat kompensasi. Bahkan Sutrisno (2009:188) menyatakan suatu perusahaan yang baik dituntut adanya sistem administrasi kompensasi yang baik pula.

Tujuan orang bekerja adalah agar dapat hidup dari hasil kerjanya. Mereka mau bekerja dikarenakan 
mereka merasa bahwa dengan bekerja ia akan mendapatkan kompensasi sebagai sumber rezeki untuk menghidupi dirinya beserta anak dan istrinya. Dengan adanya sumber nafkah tersebut, ia juga mengharapkan adanya kepastian bahwa sumber tersebut selalu ada selama ia menjadi karyawan suatu perusahaan. Oleh karena itu, tujuan perusahaan untuk memberikan kompensasi agar karyawan merasa terjamin sumber nafkahnya.

Menurut Marwansyah (2012:270), tujuan spesifik yang ingin dicapai melalui manajemen kompensasi yang efektif adalah sebagi berikut.

1. Mendapatkan karyawan yang cakap atau kompeten

2. Mempertahankan karyawan yang sudah ada

3. Menjamin terciptanya keadilan

4. Memberi penghargaan atas perilaku yang diharapkan

5. Mengendalikan biaya

6. Mengikuti peraturan-peraturan atau hukum yang berlaku

7. Menumbuhkan saling pengertian

8. Membantu menciptakan efisiensi administrasi.

Pemberian kompensasi yang layak bukan saja dapat memengaruhi kondisi materi para karyawan, tetapi juga dapat menentramkan batin karyawan untuk bekerja lebih tekun dan mempunyai inisiatif. Sebaliknya, pemberian kompensasi yang tidak layak akan meresahkan gairah kerja, sehingga prestasi kerja akan merosot. Oleh karena itu, untuk meningkatkan prestasi kerja perusahaan harus memberikan kompensasi yang layak kepada para karyawan sesuai dengan kemampuan perusahaan sendiri.

Pemberian kompensasi yang tepat waktu dapat mencegah karyawan keluar meninggalkan perusahaan. Kompensasi yang layak dan seimbang dengan jasa yang dikorbankan para karyawan. Adapun kompensasi yang tepat waktu adalah kompensasi yang diberikan perusahaan sesuai dengan waktu yang ditentukan perusahaan. Dengan pemberian kompensasi tepat waktu diharapkan bisa meningkatkan disiplin karyawan.

Perusahaan yang telah berhasil memberikan kompensasi yang layak dan tepat, akan dapat berkembang dan menghasilkan produk yang dibutuhkan masyarakat. Perusahaan yang terus berkembang tidak mungkin puas dengan penggunaan teknologi produksi seperti tahun-tahun sebelumnya. Perusahaan harus selalu dapat mengantisipasi perkembangan teknologi maju yang mutakhir dan menerapkan dalam perusahaan, sehingga perusahaan dapat selalu mengikuti perkembangan keadaan dan tuntutan perubahan zaman. Penciptaan kondisi intern yang baik dan menguntungkan memungkinkan perusahaan dapat terus lebih maju untuk mempercepat pencapaian tujuan yang telah ditentukan.

\section{Faktor-faktor yang menentukan nilai Kompensasi}

Besar kecilnya pemberian kompensasi tidak mungkin dapat ditentukan begitu saja, tanpa mengantisipasi perkembangan keadaan sekitar yang mengelilingi gerak perusahaan. Penetapan kompensasi yang hanya berdasarkan keinginan sepihak (perusahaan) saja tanpa didasarkan pada perhitunganperhitungan yang rasional dan bisa dipertanggungjawabkan secara yuridis akan sulit diterapkan dalam jangka panjang. Karena itu menurut hasibuan (2009:128), ada anggapan bahwa besar kecilnya kompensasi akan selalu dipengaruhi oleh beberapa faktor, di antaranya:
1. Penawaran dan Permintaan Tenaga Kerja 
Jika pencari kerja (penawaran) lebih banyak daripada lowongan pekerjaan (permintaan) maka kompensasi relatif kecil. Sebaliknyan jika pencari kerja lebih sedikit daripada lowongan pekerjaan, maka kompensasi relatif semakin besar.

2. Kemampuan dan Kesediaan Perusahaan

Apabila kemampuan dan kesediaan perusahaan untuk membayar semakin baik maka tingkat kompensasi akan semakin besar. Tetapi sebaliknya, jika kemampuan dan kesediaan perusahaan untuk membayar kurang maka tingkat kompensasi relatif kecil.

3. Serikat Buruh/ Organisasi Karyawan

Apabila serikat buruhnya kuat dan berpengaruh maka tingkat kompensasi semakin besar. Sebaliknya jika serikat buruh tidak kuat dan kurang berpengaruh maka tingkat kompensasi relatif kecil.

4. Produktivitas Kerja Karyawan

Jika produktivitas kerja karyawan baik dan banyak maka kompensasi akan semakin besar. Sebaliknya kalau produktivitas kerjanya buruk serta sedikit maka kompensasinya kecil.

5. Pemerintah dengan UndangUndang dan Keppres

Pemerintah dengan undangundang dan keppres menetapkan besarnya batas upah atau balas jasa minimum. Peraturan pemerintah ini sangat penting supaya pengusaha tidak sewenang-wenang menetapkan besarnya balas jasa bagi karyawan. Pemerintah berkewajiban melindungi masyarakat dari sewenangwenang.
6. Biaya Hidup/ Cost of Living

Apabila biaya hidup di daerah itu tinggi maka tingkat kompensasi atau upah semakin besar. Sebaliknya, jika tingkat biaya hidup di daerah itu rendah maka tingkat kompensasi atau upah relatif kecil.

7. Posisi Jabatan Karyawan

Karyawan yang menduduki jabatan lebih tinggi akan menerima gaji atau kompensasi lebih besar. Sebaliknya karyawan yang menduduki jabatan yang lebih rendah akan memperoleh gaji atau kompensasi yang kecil. Hal ini wajar karena seseorang yang mendapat kewenangan dan tanggung jawab yang besar harus mendapatkan gaji atau kompensasi yang lebih besar pula.

8. Pendidikan dan Pengalaman Karyawan

Jika pendidikan lebih tinggi dan pengalaman kerja lebih lama maka gaji atau balas jasanya akan semakin besar, karena kecakapan serta keterampilannya lebih baik. Sebaliknya, karyawan yang berpendidikan rendah dan pengalaman kerja yang kurang maka tingkat gaji/ kompensasinya kecil.

9. Kondisi Perekonomian Nasional

Apabila kondisi perekonomian nasional sedang maju (boom) maka tingkat upah atau kompensasi akan semakin besar, karena akan mendekati kondisi full employment. Sebaliknya, jika kondisi perekonomian kurang maju (depresi) maka tingkat upah rendah, karena banyak penganggur (disqueshed unemployment)

10. Jenis dan Sifat Pekerjaan

Kalau jenis dan sifat pekerjaan yang sulit dan mempunyai risiko (finansial, keselamatan) yang besar maka tingkat upah atau 
balas jasanya semakin besar karena membutuhkan kecakapan serta ketelitian untuk mengerjakannya. Tetapi jika jenis dan sifat pekerjaannya mudah dan risiko (finansial, kecelakaannya) kecil, tingkat upah atau balas jasanya relatif rendah.

\section{E. Langkah-langkah kompensasi}

penentuan

Penentuan kompensasi yang pasti, tidak hanya memberikan rasa ketenangan bagi pegawai atau karyawan saja, tetapi bagi perusahaan dapat digunakan untuk berapa besar anggaran biaya pegawai yang harus dikeluarkan oleh perusahaan secara periodik. Menurut rachmawati (2008:148) untuk penentuan kompensasi tersebut, ada beberapa langkah yang dapat digunakan, yaitu:

1. Menganalisis jabatan, yaitu kegiatan untuk mencari informasi tentang tugas-tugas yang dilakukan dan persyaratan yang diperlukan dalam melaksanakan tugas tersebut.

2. Mengevaluasi jabatan, yaitu proses sistematis untuk menentukan nilai relatif dari suatu pekerjaan dibandingkan dengan pekerjaaan lain.

3. Melakukan survei gaji dan upah, yaitu kegiatan untuk mengetahui tingkat gaji yang berlaku secara umum dalam perusahaanperusahaan yang mempunyai jabatan yang sejenis, ini dilakukan untuk mengusahakan keadilan eksternal sebagai salah satu faktor penting dalam perencanaan dan penentuan gaji dan upah. Survey dapat dilakukan dengan berbagai macam cara seperti mendatangi perusahaan-perusahaan untuk mendapatkan informasi mengenai tingkat gaji dan upah yang berlaku, membuat kuesioner secara formal dan sebagainya.

Menurut Hanggraeni (2012:143) tujuan utama survey gaji adalah untuk mengetahui seberapa besar perusahaan lain yang bergerak di bidang yang sejenis memberikan gaji kepada jabatan-jabatan yang sama. Apabila perusahaan membayar lebih tinggi gaji untuk jabatan yang sejenis dibandingkan dengan umumnya perusahaan lain di pasar maka perusahaan tersebut berada di posisi higher market level. Sebaliknya, apabila lebih rendah maka perusahaan tersebut berada di posisi below market level.

4. Menentukan tingkat gaji, yaitu penentuan gaji sesuai dengan rangking jabatan, misalnya menggunakan metode poin, faktorfaktor pekerjaan telah ditentukan poinnya dan jabatan-jabatan kunci telah diketahui harga pasarnya berdasarkan survey yang dilakukan. Selanjutnya berdasarkan poin yang sudah ditentukan dengan cara mempelajari informasi analisis jabatan setiap pekerjaan ditentukan poinnya.

\section{F. Kesimpulan dan saran}

Salah satu tujuan yang diinginkan dalam manajemen sumber daya manusia adalah pencapaian tujuan organisasi. Untuk itu salah satu variabel yang harus menjadi perhatian bagi pimpinan organisasi dalam menjalankan roda organisasi adalah kompensasi. Beberapa faktor yang dapat menentukan nilai kompensasi bagi seorang pegawai di suatu organisasi adalah penawaran dan permintaan tenaga kerja, kemampuan dan kesediaan perusahaan, serikat buruh atau organisasi karyawan, 
produktivitas kerja karyawan, pemerintah dengan undang-undang dan keppres, biaya hidup atau cost of living, posisi jabatan karyawan, pendidikan dan pengalaman karyawan, kondisi perekonomian nasional, jenis dan sifat pekerjaan. Sedangkan langkah-langkah yang harus dilakukan dalam rangka menentukan nilai kompensasi bagi seorang pegawai disuatu organisasi adalah menganalisis jabatan, mengevaluasi jabatan, melakukan survey gaji dan upah, kemudian terakhir menentukan tingkat gaji.

Penulis menyarankan kompensasi yang diberikan sebaiknya dapat dirasakan adil oleh pegawai, dan besarnya kompensasi tidak jauh berbeda dengan yang diharapkan oleh pegawai. Apabila dua hal ini dapat dipenuhi, diharapkan pegawai akan merasa puas. Kepuasan ini akan memicu pegawai untuk terus meningkatkan kinerjanya, sehingga tujuan organisasi maupun kebutuhan pegawai akan tercapai secara bersama.

\section{DAFTAR PUSTAKA}

Djaali. 2011. Psikologi Pendidikan. Jakarta: Bumi Aksara.

Gomes, Faustino Cardoso. 2003. Manajemen Sumber Daya Manusia. Yogyakarta: Andi Offset Hanggraeni, Dewi. 2012. Manajemen Sumber Daya Manusia. Jakarta: Lembaga Penerbit Fakultas Ekonomi Universitas Indonesia.

Hasibuan, Malayu S. P. 2012. Manajemen Sumber Daya Manusia. Jakarta: PT Bumi Aksara.

Marwansyah. 2012. Manajemen Sumber Daya Manusia. Bandung: Alfabeta.

Rachmawati, Ike Kusdyah. 2008. Manajemen Sumber Daya
Manusia. Yogyakarta: Penerbit Andi.

Rivai, Veithzal Rivai dan Ella Jauvani Sagala. 2010. Manajemen Sumber Daya Manusia untuk Perusahaan. Jakarta: Rajawali Pers.

Sihotang, A. 2007. Manajemen Sumber Daya Manusia. Jakarta: Pradnya Paramita.

Singodimedjo, Markum. 2000. Manajemen Sumber Daya Manusia. Surabaya: SMMAS.

Sunyoto, Danang. 2015. Manajemen dan Pengembangan Sumber Daya Manusia. Yogyakarta: CAPS.

Sutrisno, Edy. 2009. Manajemen Sumber Daya Manusia. Jakarta: Kencana. 